\title{
Drawing and the Remembered City
}

\section{Anne Howeson - Royal College of Art}

The following article was presented as a paper at Shaping the View: Understanding Landscape through Illustration, The $7^{\text {th }}$ International Illustration Research / Journal of Illustration Symposium. 10 -11 November, Edinburgh College of Art, Scotland.

\section{Keywords}

Drawing, place, time, memory, illustration, archives, metaphor.

\begin{abstract}
This article discusses place, memory and drawing. It suggests that 'place' can be a key theme for illustrators and artists - a container and metaphor for social, political and historical ideas. Using personal case studies, memory is considered as a storeroom of ideas with a close connection to the imagination. Atmosphere, mood and the role of colour, light and shadow are presented as primary ways of communicating complex ideas through intuition and emotion, in addition to the language of intellect, reason and the conceptual.
\end{abstract}

The urgent shorthand nature of drawing is a direct conduit to the unconscious. This article suggests that memory and drawing can work together to trigger unexpected imagery and make imaginative predictions. It looks at the experience of making drawings while situated within a landscape or environment in contrast to using memory or other references away from the scene. These issues are examined in the context of two solo drawing projects concerning the urban landscape of King's Cross London, both of which use memory and drawing, visually and conceptually - in different ways.

The first: 'Remember Me' - Guardian Media 2009 - commemorated the disappearing buildings of King's Cross and St. Pancras and imagined a fictitious architectural future.

The second: 'Present in the Past' - Collyer Bristow 2015, worked with copies of engravings from London prints and drawings archives, changing their scale, context and content (by erasing and re drawing) to interweave time and memory into a kind of palimpsest.

'Forgetting is a strange power, because it makes memory possible. That is why all architecture from the past is something like the music of space, which surrounds us and sends us images that we have constantly to interpret.'

Hertmans, Stefan 2001 Intercities 
I am an artist and illustrator. Much of my work responds to the idea of place and the people who inhabit it. Place, and the memory of place has also influenced my thinking as a lecturer. The places in my drawings - either real or imagined, including landscape and built environments, are expressed through memory, time and atmosphere. I am interested in the way locations and environments are responded to directly from life, but can also be containers and metaphors for stories, concepts and reimagined ideas. Metaphor in landscape and place is capable of expressing complex conceptual ideas by evoking atmosphere through colour, light and shade. Artists and illustrators may choose to work with any of these options.

The rural countryside near the North Downs in Kent was my first home. It was a place of tranquility and calm. Samuel Palmer lived in the nearby village of Shoreham in the early nineteenth century, his visionary and mystical first paintings influenced my own early work

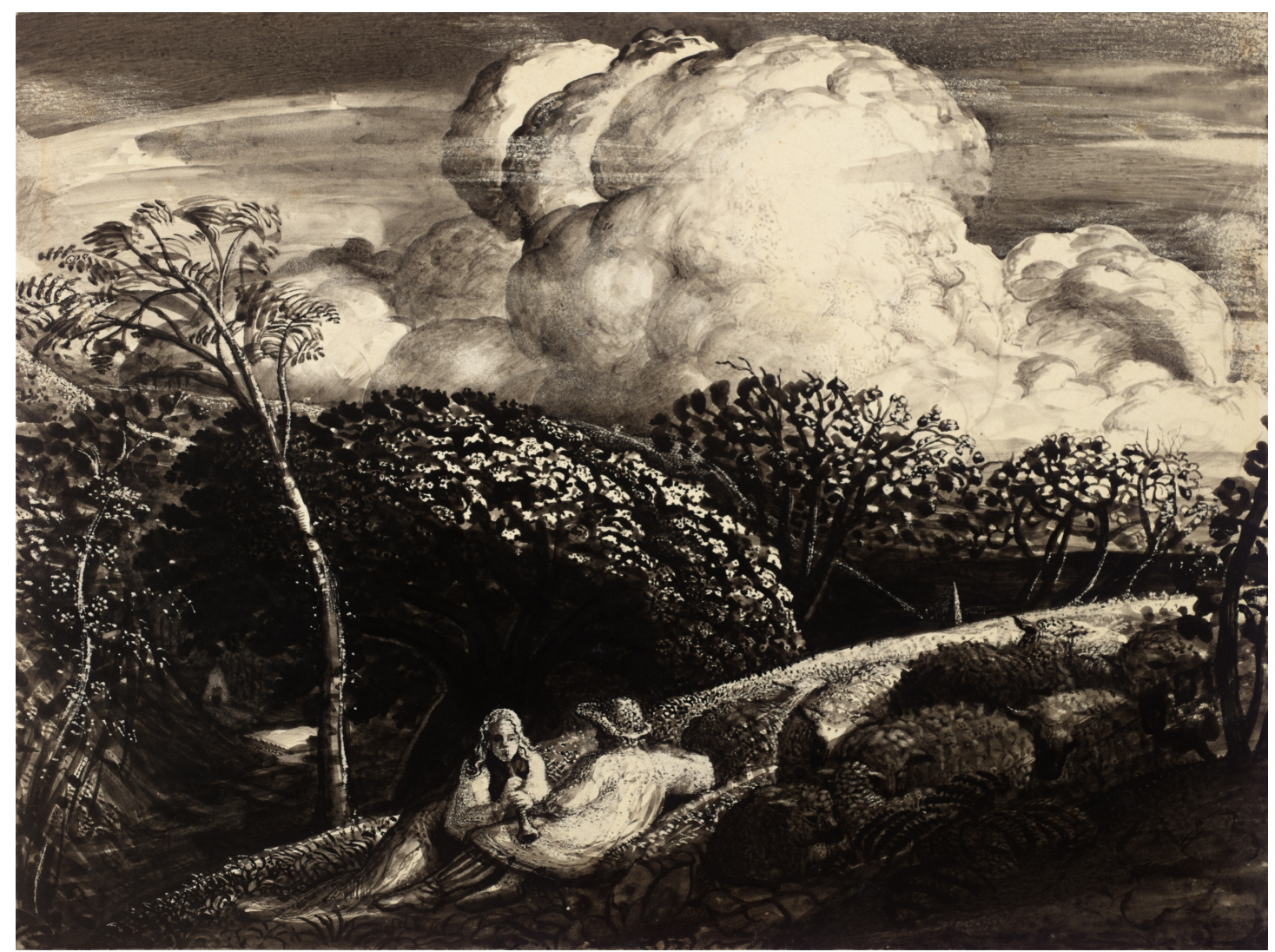

Figure 1 Palmer, Samuel (1833-34) The Bright Cloud ink and watercolour $22.9 \mathrm{~cm} \times 30.5 \mathrm{~cm}$, image reproduced with permission

Our modern house overlooked fields on the edge of an estate designed by Robert Adam with grounds by Capability Brown. We moved there when I was about three years old and the beauty of its setting has stayed in my imagination ever since. From a small bathroom window, I could stare out at the formal landscape, which my father's binoculars transformed into something dreamlike. Brown's carefully designed landscape included features such as a ha 
ha wall (a quirky kind of wall which takes a step down and forms a boundary between an estate's gardens and grounds, giving a clear view over a landscape and stopping the cows from getting in, without the need of a fence). Copses of trees were planted on the brow of rolling hills, cutting into the existing landscape like a huge drawing made of earth and stone.

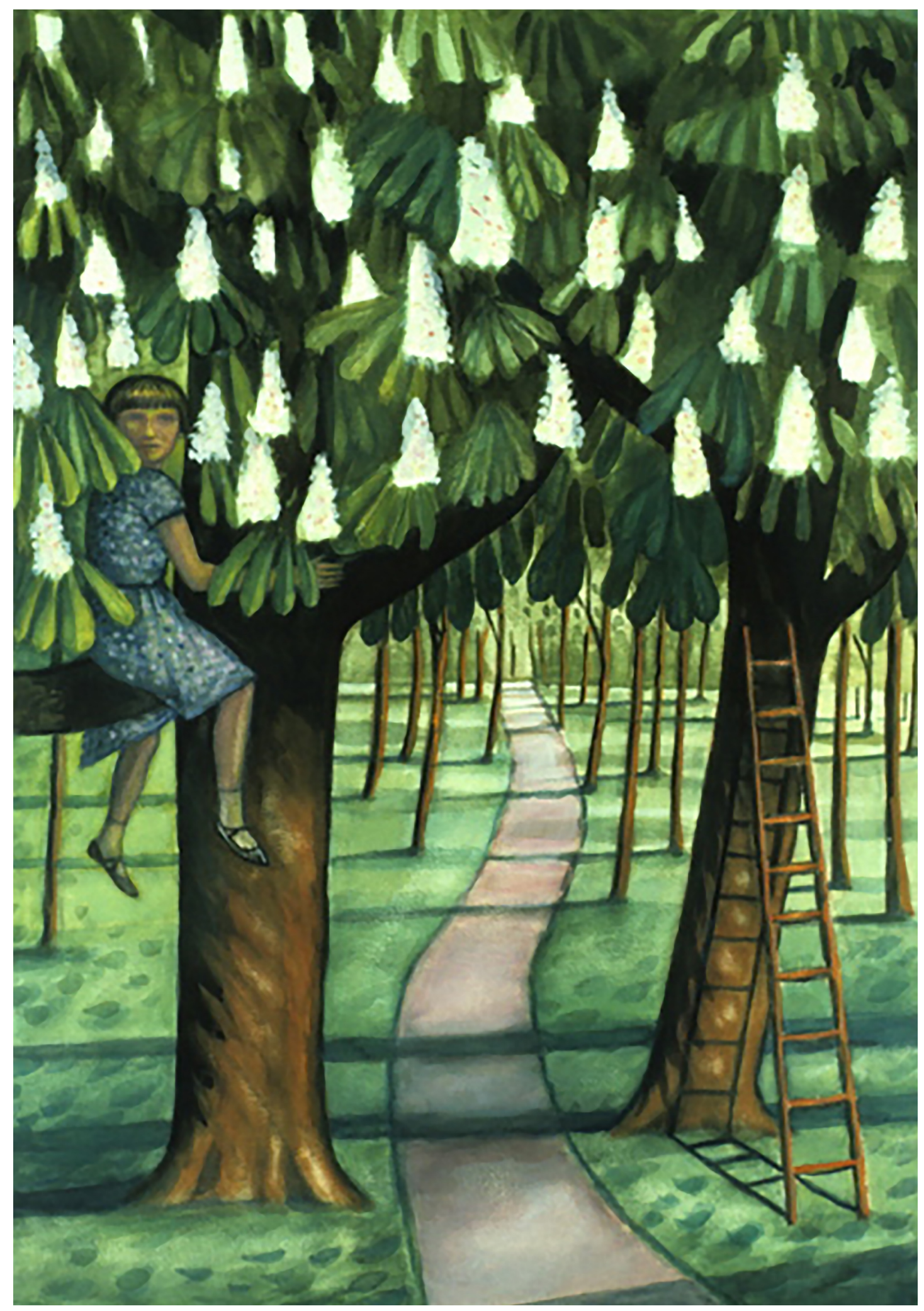

Figure 2 Howeson, Anne (1993) Chestnut tree gouache $60 \mathrm{~cm} \times 40 \mathrm{~cm}$ 
There were tall trees in our garden and I had a reckless impulse to climb to the top of them (inspired by Enid Blyton's The Faraway Tree). I especially liked climbing into a huge old chestnut tree in Spring when the blossoms were out - pretending to be Queen of the May

It is said that formative events before the age of 17 have an influence on everything that follows. Mine was the early loss of my parents. After they died I often dreamed about returning to the house and its surroundings - but it was no longer recognizable.

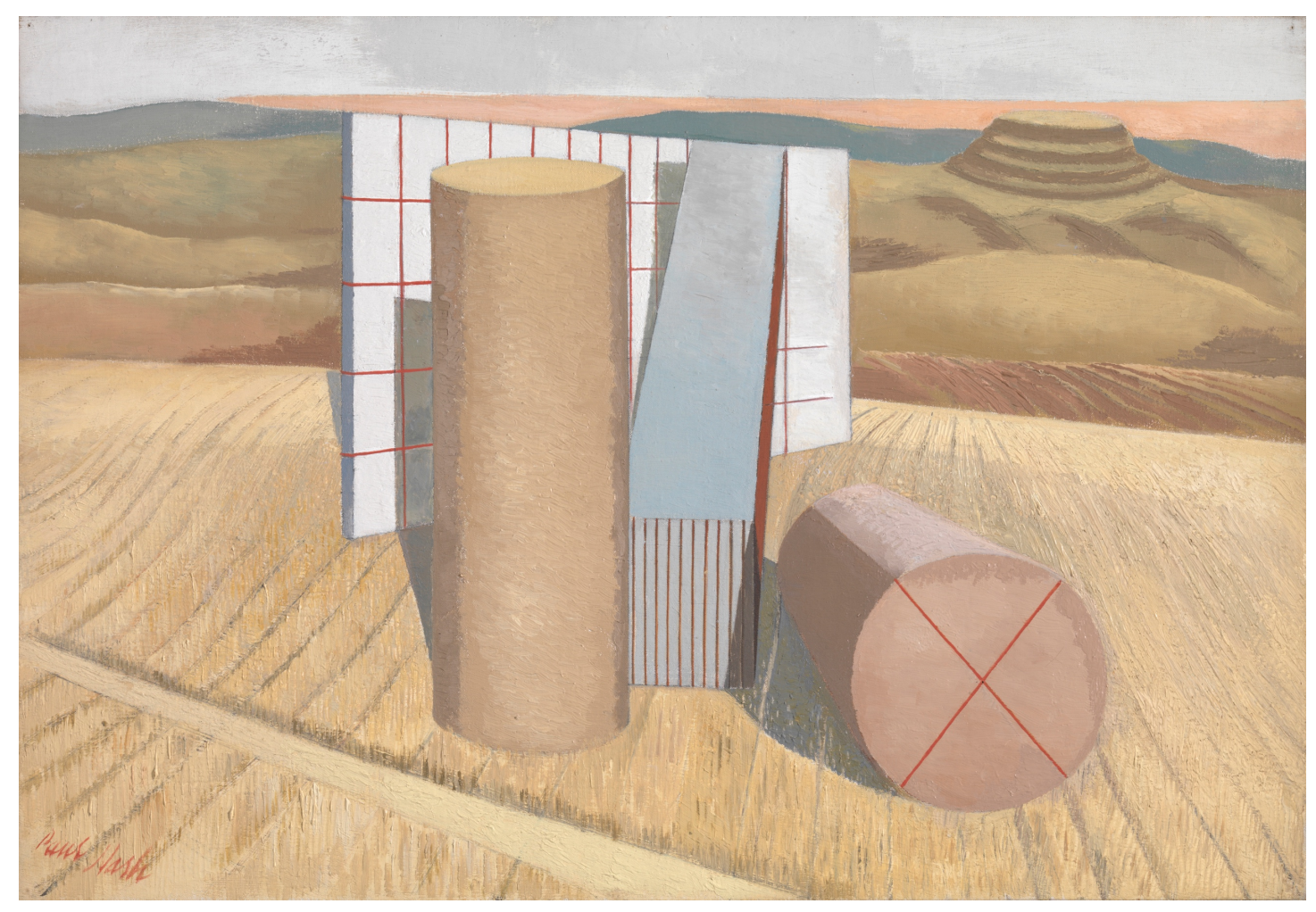

Figure 3 Nash, Paul (1935) Equivalents for the Megaliths $45.7 \mathrm{~cm} \times 66.00 \mathrm{~cm}$ oil paint, image reproduced with permission

The countryside nearby was similar to the hilly landscapes in the paintings of Paul Nash (1889 -1946), whose metaphysical interpretation of landscape always intrigues me. I cannot remember whether I knew about his paintings early on, or if I discovered him because of the landscape where I grew up. When Nash became less mobile, later in life, he also used binoculars as a way of transporting himself visually across the space between himself and his motif, saying: 'my love of the monstrous and the magical led me beyond the confines of natural appearances into unreal worlds.' Most of his work seems to grow from imagination rather than reality and observation - in contrast to the paintings by his brother John Nash (1893-1977), which, though expressive and structurally strong, relate more directly to the real world. 
At the age of ten, I was sent to school in Surrey. It was lonely there, and I did not fit in. Art and literature became my refuge and the landscape surrounding the school my inspiration. I loved exploring the chalky downs, reading and drawing in the fields during the summer months.

An important early influence was Pieter Bruegel the Elder (1525-1569). There's a darkness as well as sense of energy and life in his paintings, and the golden idealised landscapes, teeming with people toiling in fields or dancing, drinking and eating seem to contradict the severity of the people's lives depicted within them.

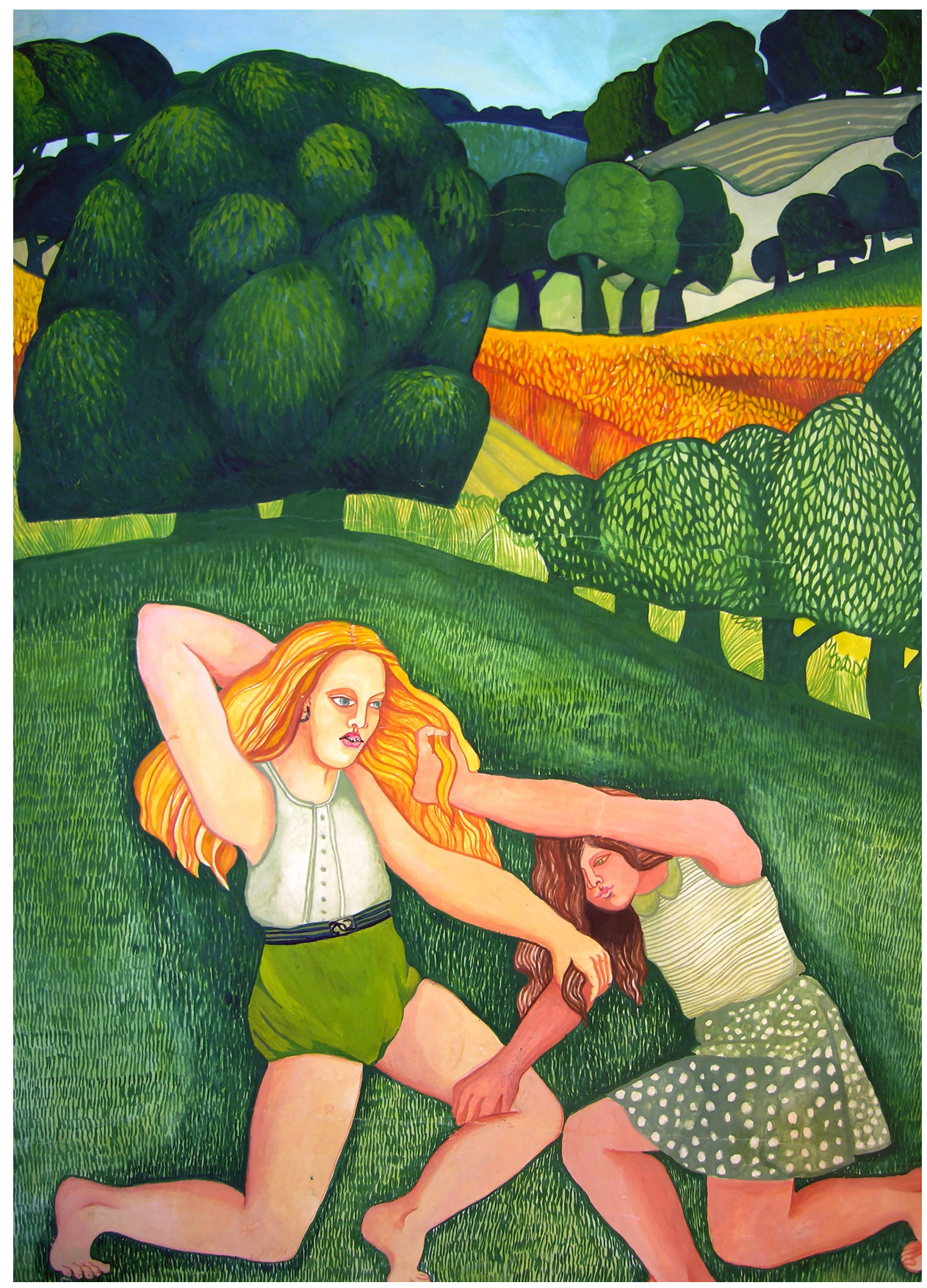

Figure 4 Howeson, Anne (1966) Two Girls Fighting, $50 \mathrm{~cm} \times 35 \mathrm{~cm}$ gouache 
Looking back, I realise the rural settings where I lived until the age of nineteen informed my whole future artistic world. As a child I wrote about the trees, fields and sky outside our windows and made drawings of the landscape near our house, including a triptych about a car journey.

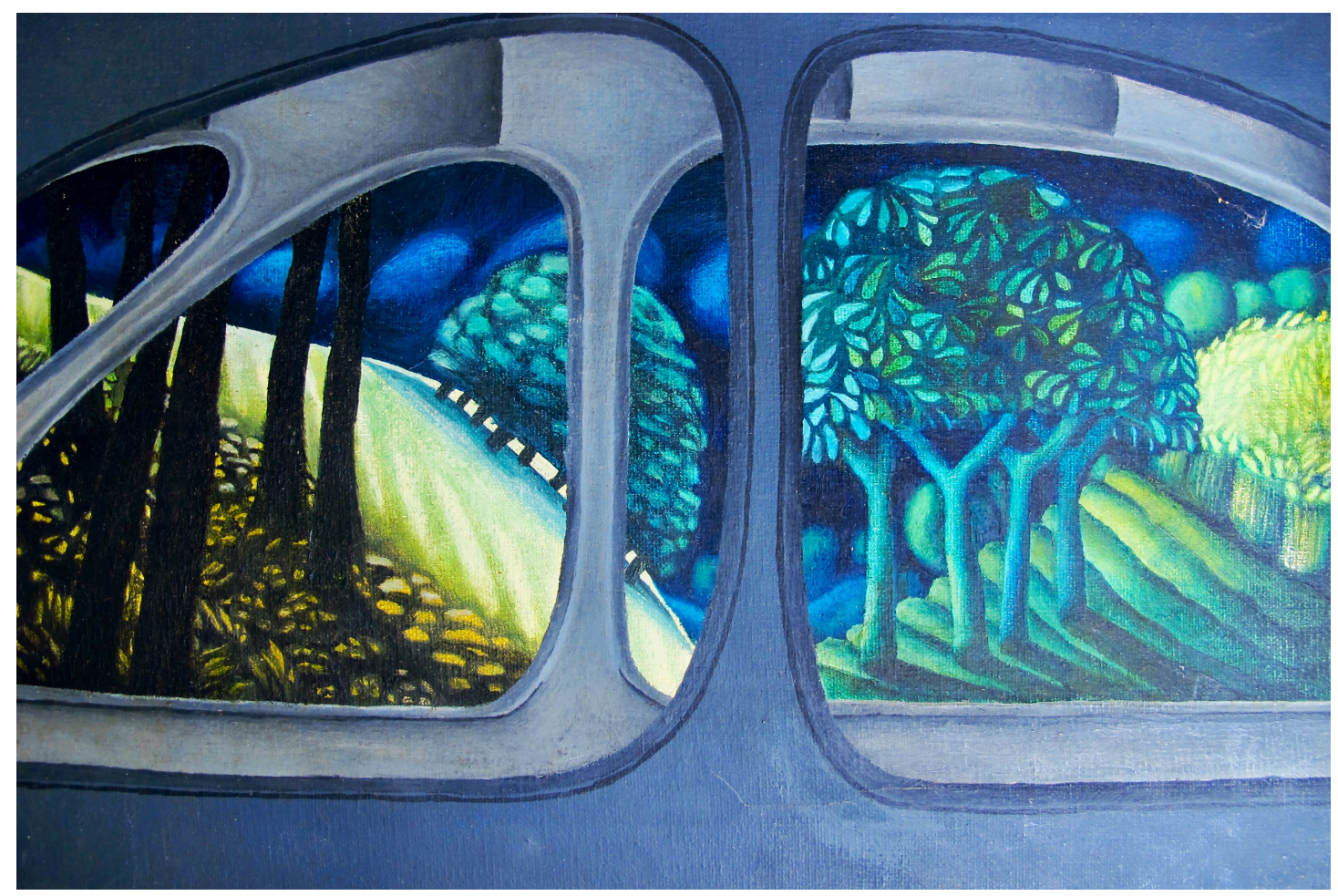

Figure 5 Howeson, Anne (1968) Car Journey $25 \mathrm{~cm}$ x $35 \mathrm{~cm}$ oil on canvas

At the same age one of my poems was included in 'Fire Words' - a book of children's poetry in 1971, edited by Chris Searle, and published in the Times newspaper for a competition called 'My Future'.

\section{My Future}

A midnight Jet

can hardly be identified

on dark and unknown expeditions of the sky,

as more than a passing engine -

an unseen mechanism, progressing

through heights unrealized inside late houses.

But I looked up last night

and read in the quiet sky

the exact passage of the pilots

and fifty hidden people

seated and ascending the evidence of a journey 


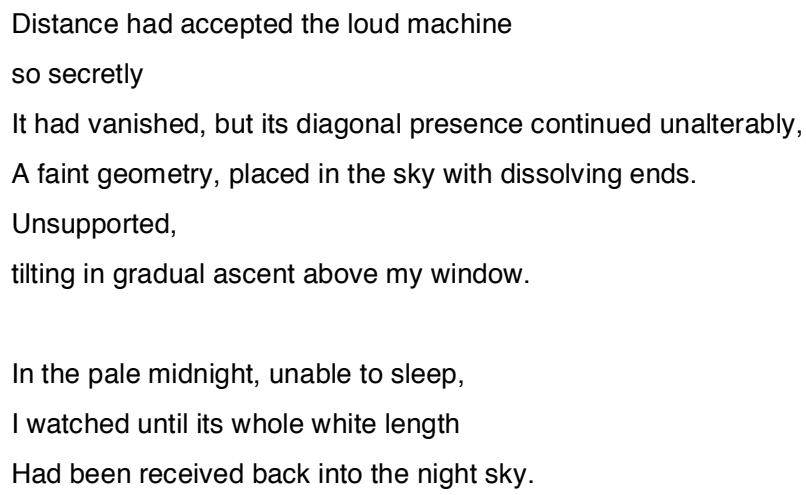

\section{Anne Howeson 1969}

These days I work mostly for exhibition but sometimes to commission. Being constrained by a brief is excellent training for personal work because it forces us to be inventive. New developments emerge when you have to think beyond what you know already.

Drawing is my primary working method. I like its scratchy nature, the use of a hard instrument scraping on a dry surface such as paper. Cutting across all art disciplines, drawing has a broad and crucial role to play, but its definition is hard to pin down. One important quality is a timelessness: the ability to exist outside the constraints of fashion and art history, creating links between the past and the present which are startling and remind us of a continuity in our common humanity. Drawings from the past sometimes look surprisingly modern because technically and conceptually, we recognize characteristics that are respected in our own time: qualities of spontaneity and simplicity, directness, rawness and expressiveness.

William Kentridge said: 'Drawing is a testing of ideas - a slow motion version of thought.' 2003. A sample list of its other uses might include: diagrams, doodles, notes and measurements, instructions to communicate with oneself or others, sketches towards finished designs, resolved works of art, private musings, works from observation, memory and imagination, and drawing as thinking. When we develop ideas through drawing, the act of making seems to emerge out of or extend the intellectual connection. Working instinctively, we almost 'discover' thoughts and imaginings, as though extracting water from a well. This quality of immediacy, like handwriting, is a lightning conductor between thinking and making.

I believe drawing has an uncanny predictive quality, agreeing with Josef Herman: 'Drawing always knows better than I what I want to say.' The illustration below was a commission from the European Union. They provided the phrase: 'Freedom for the individual' but left the brief open. My idea was to show a diverse group of people walking in a sunny landscape expressing themselves as individuals. But this image is an example of drawing as prediction, 
because the figure behind the tall woman in the middle turned out to be a portrait of my future husband. I did not meet him until the following year.

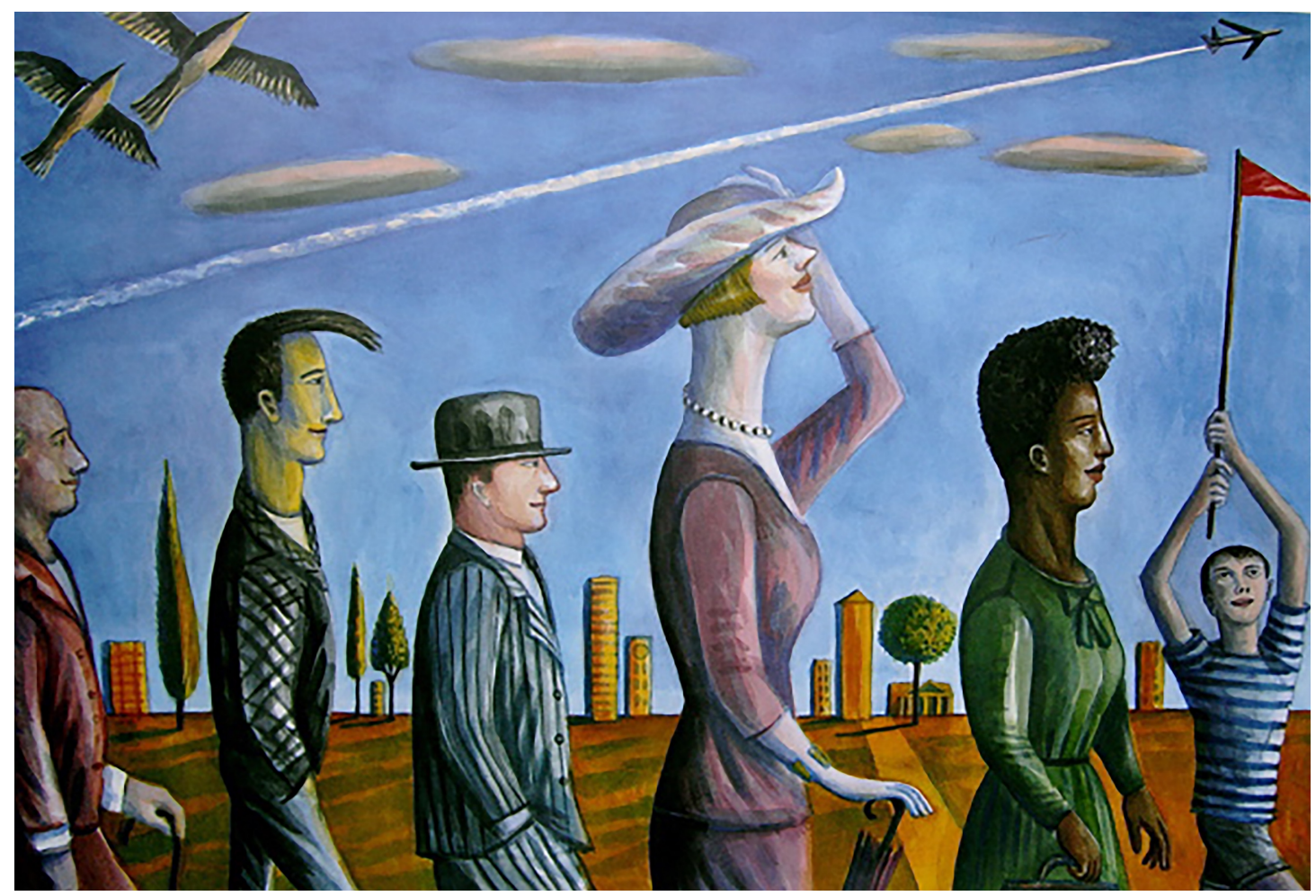

Figure 6 Howeson, Anne (1994), Freedom for the Individual, $500 \times 400 \mathrm{~cm}$ gouache

In this digital age, I ask myself why I am attached to drawing. The answer is complex. One reason I keep drawing is because it takes so long to become any good at it. Another reason is that I love its physicality - in some ways drawing is like a gentle manual labour. My two older sisters and I are all practical: as teenagers we liked to sew and make things together.

Influenced by the early Italian artists Giotto, Sassetta and Masaccio, I planned to study painting at Art School, and to tell stories. However, painting courses at that time appeared to be stuck in Abstract Expressionism so I applied to the BA Graphic Design Course at St Martins (to study illustration), followed by an MA in illustration at the Royal College of Art where the inspirational Quentin Blake was Head of Department.

I was offered a residency in Paris in the summer of 1976, arriving in the month of May - just as the trees were coming into leaf for a summer that was to be exceptionally long and hot. The impact of Paris was dramatic and powerful. I fell in love with it as a place and was happy to spend all day walking the streets, making drawings from life. 


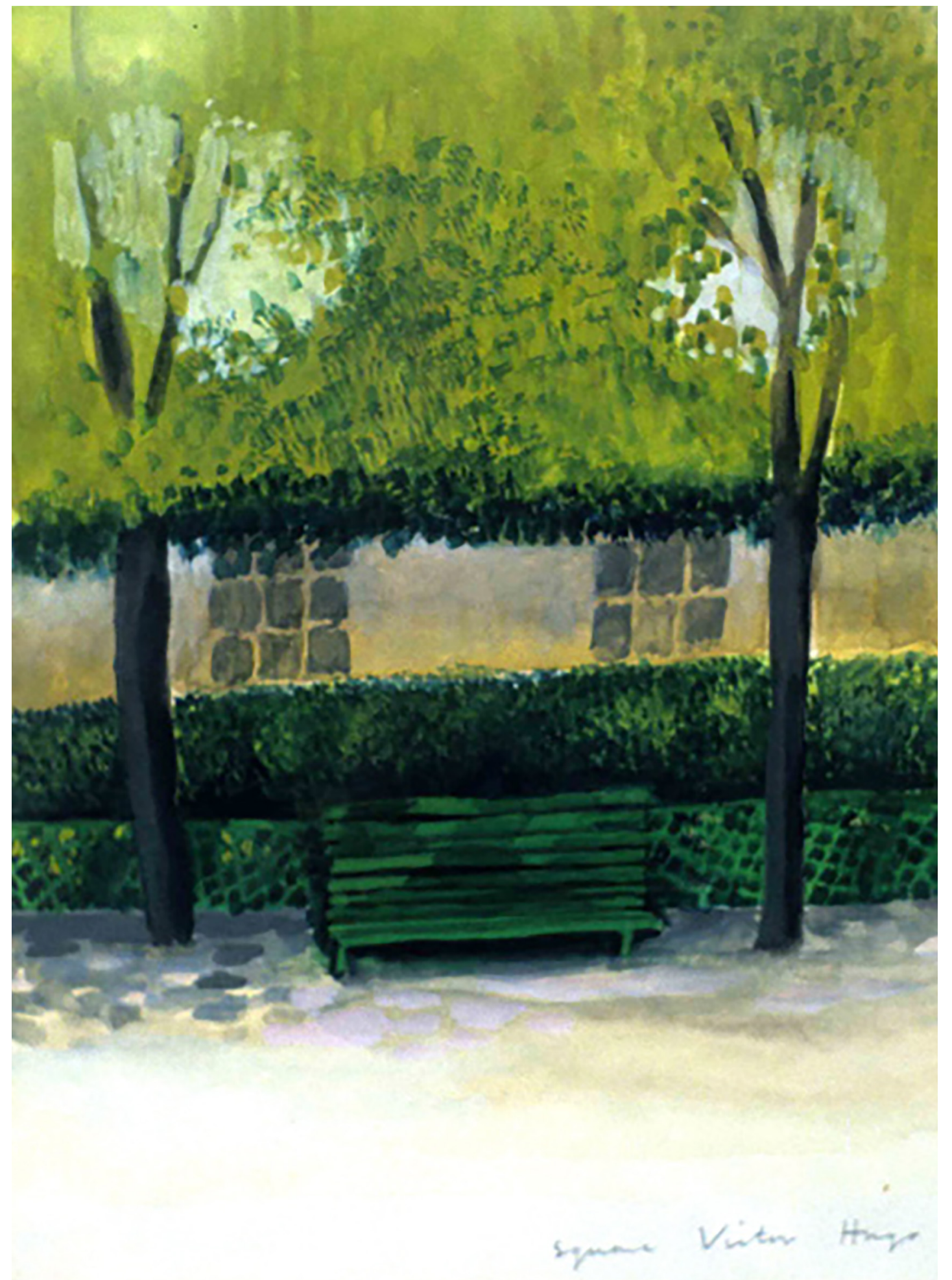

Figure 7 Howeson, Anne (1976) Paris memory gouache $18 \mathrm{~cm} \times 23 \mathrm{~cm}$

My first experiments with 'memory' drawings began at that time. Back in the apartment after roaming the city, l'd recall from memory the images seen on the streets of Paris during the day. They seemed to project onto my mind like glowing tableaux: a little solitary bench in the corner of a dusty square, a single lit window at the top of a high building along the River Seine, with the moon appearing above its roof behind clouds. The atmospheric lighting along 
the banks of the Seine (long before floodlighting came to London) was especially magical - a son et lumière theatrical performance using the whole of Paris as a backdrop.

The colour drawings from memory in Paris were made a few hours after the experience itself. However, it's interesting to make 'memory' drawings at a much later stage - when the recollection has faded and an effort of imagination is needed to draw an image back up into focus. 'Memory' drawings (whether about people, places or incidents), distill an essence absorbed at the moment of an experience, evoking an emotional feeling or association experienced at the earlier time, as, when we unexpectedly smell something familiar from the distant past, a long forgotten memory suddenly resurfaces.

I planned my first socially engaged drawings after wandering through Pigalle and Rue St Denis where the prostitutes worked.

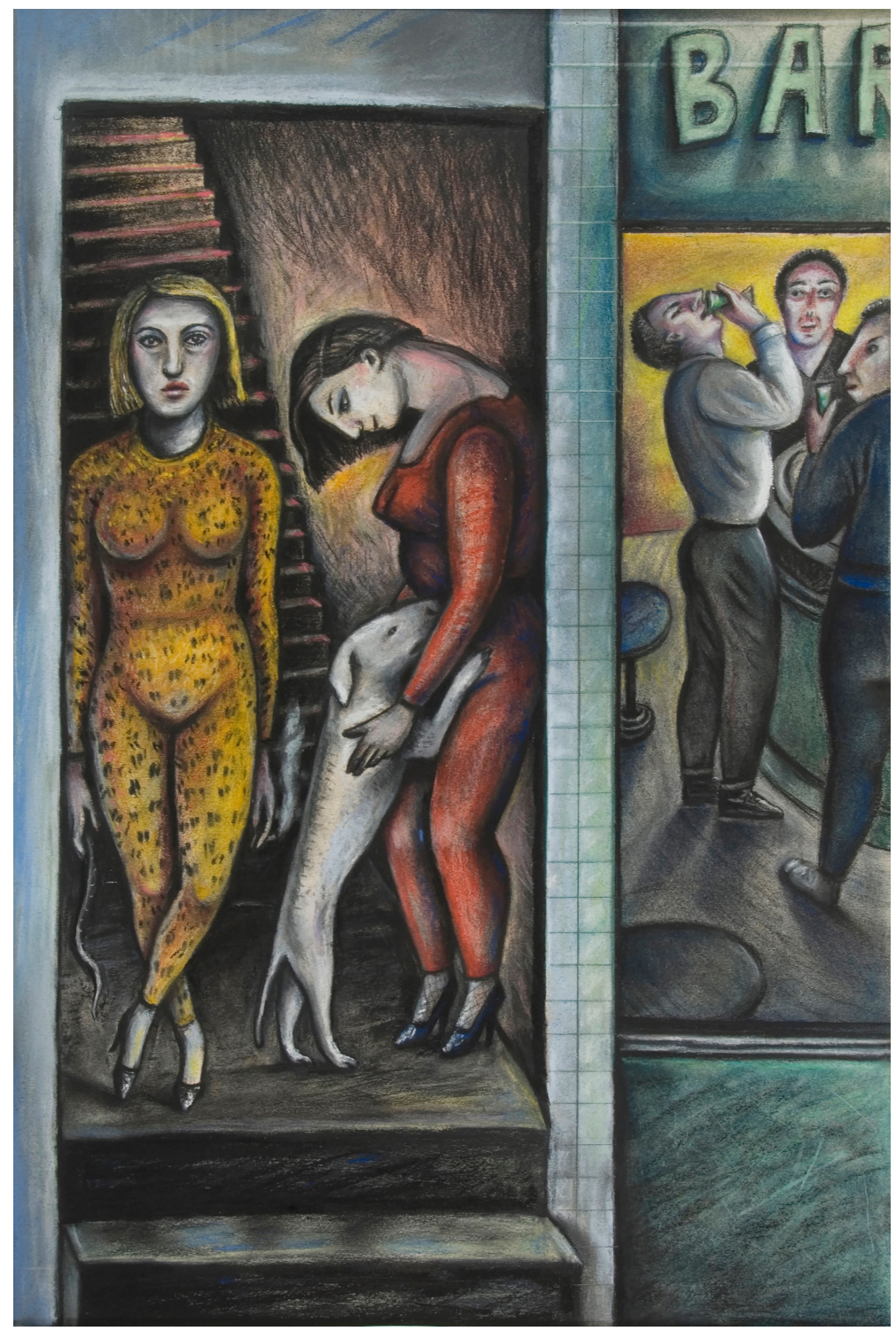

Figure 8 Howeson, Anne, (1981) Two Prostitutes and their Dog pastel $28 \mathrm{~cm} \times 41 \mathrm{~cm}$ 
This is one of a series of drawings on prostitution (from the exhibition: 'Business: Three Views on Sex for Sale' Thumb Gallery, Soho 1981). I didn't want to document the prostitutes so much as put myself in their shoes and try to understand how and why they choose their profession. Wandering at night in Rue St Denis I made rough drawings in a sketch book from a distance and watched them making assignations on street corners and meeting friends for coffee. Identifying with their need to earn an independent living, I wanted to talk to them and find out more about their lives, but was too scared to approach. The one time I did, I got snarled at and dismissed, so I watched from a distance instead, and made drawings from memory later. In 'Two Prostitutes and their Dog' two women wait in a doorway, chatting to each other and playing with their dog, while men in the bar next door are drinking. Unintentionally the central character in leopard skin slightly resembles me. This tendency to use one's own face in drawings happens naturally - it's the unconscious outcome of being familiar with a particular form. What is perhaps stranger is that the small white dog in the picture is just like the dog I now have - another example of drawing as prediction?

It's good to discover imagery from both real and imagined worlds, because different possibilities emerge from both. The idea of using memory and of inventing and fictionalizing places is compelling, but so too is the unfashionable experience of working directly from life in the open air. Sometime after leaving the RCA, having been a commercial illustrator for a long time and possibly in reaction to being typecast as making dark and provocative imagery, I wanted to express a more lyrical side by working from observation, in English gardens. However, an intrinsic darkness always emerges in these drawings whether I want it to or not. 


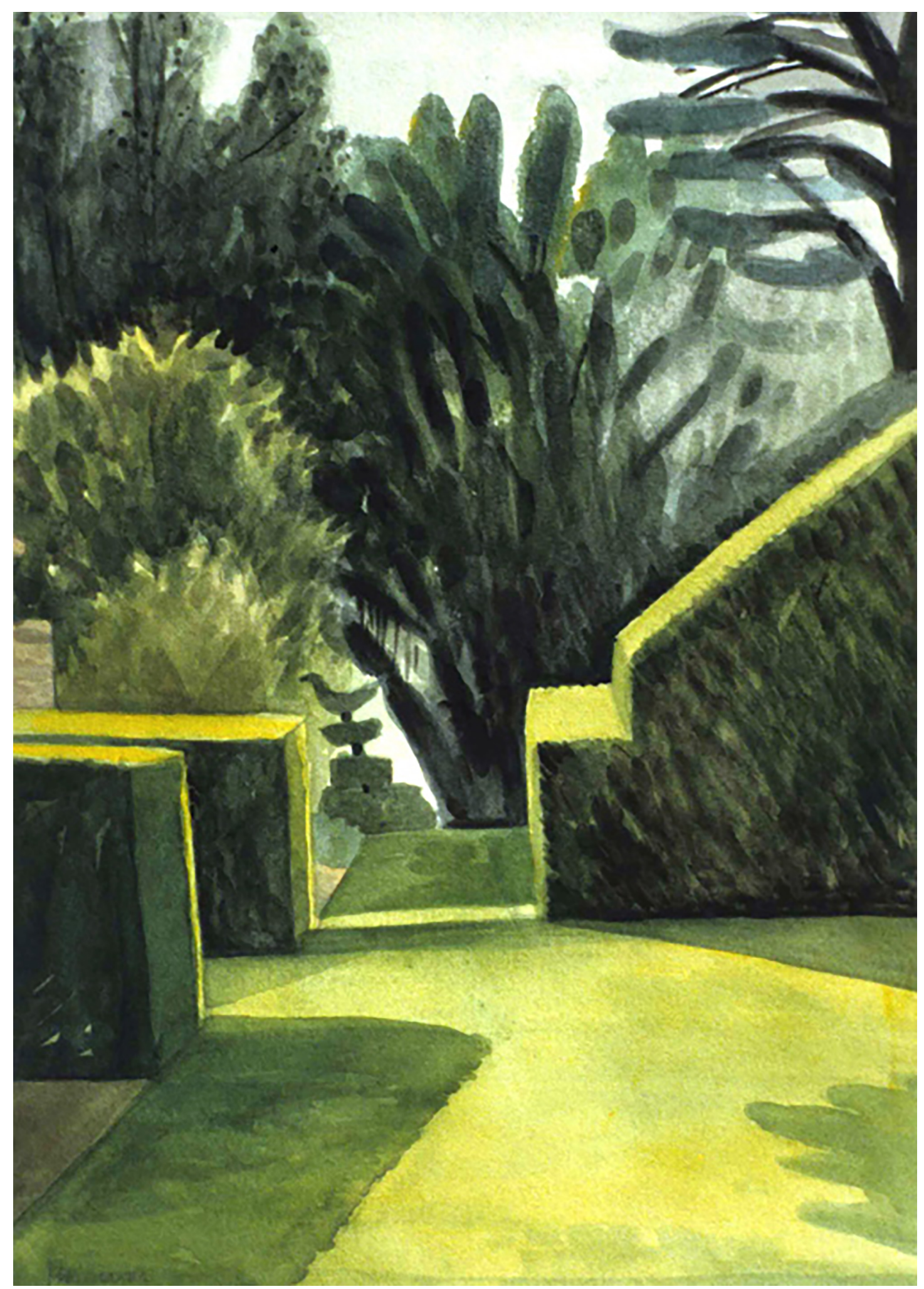

Figure 9: Howeson, Anne (2000) Garden gouache 290 x $410 \mathrm{~cm}$

Perhaps early memories of Capability Brown's landscape created my interest in formal gardens. Mysterious and atmospheric with their clipped topiary hedges, it is wonderful to experience them on hot summer days when the long dark shadows transform them into stage sets. 
There's a delight, a sense of being in the moment, that comes from working outside. At first you think you'll never find the right place, but after a couple of hours that deadening sense of self disappears and you're mesmerized into a kind of timeless meditation as you work.

Last summer in the Abruzzo in Italy, I spent a hot afternoon sitting on a little fishing stool on the shallow stony bed of the River Aterno making a drawing. While working on it, I felt so absorbed that I forgot about my surroundings - until becoming aware of a big shaggy basket moving in the middle distance when I stood up to get a better look. The basket (a wild boar) swayed for a while then scurried away, panic stricken. A tall grey heron flapped noisily out of the undergrowth directly in front of me, followed by silence. I went back to work on the picture. Then a gigantic crash and splash made me turn just in time to catch sight of a second wild boar scrambling up the steep bank towards the high mountains.

\section{'Remember Me'}

Two of my solo shows have been about regeneration in the largest area of urban redevelopment in Europe - King's Cross/St Pancras, London. They are also concerned with place, memory and drawing. The first exhibition: 'Remember Me', Guardian Media, 2009, commemorated the disappearing buildings and imagined a fictitious architectural future in King's Cross.

Building sites have an excitement and an instability that's ambiguous and compelling (see Frank Auerbach's 1952-1962 London Building Sites sketches). When I started work on the drawings for 'Remember Me', King's Cross was both a ruin and a new neighbourhood in construction. Few of the old buildings had yet been dismantled and the area was at the beginning of a transition that would continue for the next ten to fifteen years (and is still ongoing) - with a growing and shifting population. I was motivated by a feeling of loss and nostalgia for a place with an atmosphere that was frozen in time, scruffy, even dangerous - a place which hadn't yet disappeared but whose days were numbered.

It was this 'in between' state that intrigued me. I spent evenings wandering the streets near the station, with sketchbook and camera, recording the pulling down and raising up of buildings in the sleeping railway lands. The drawings are not a representational document, more an attempt to hold on to a memory and invent a fictional future for the places I knew so well. Most of the content was architectural - there were almost no people in the streets. 


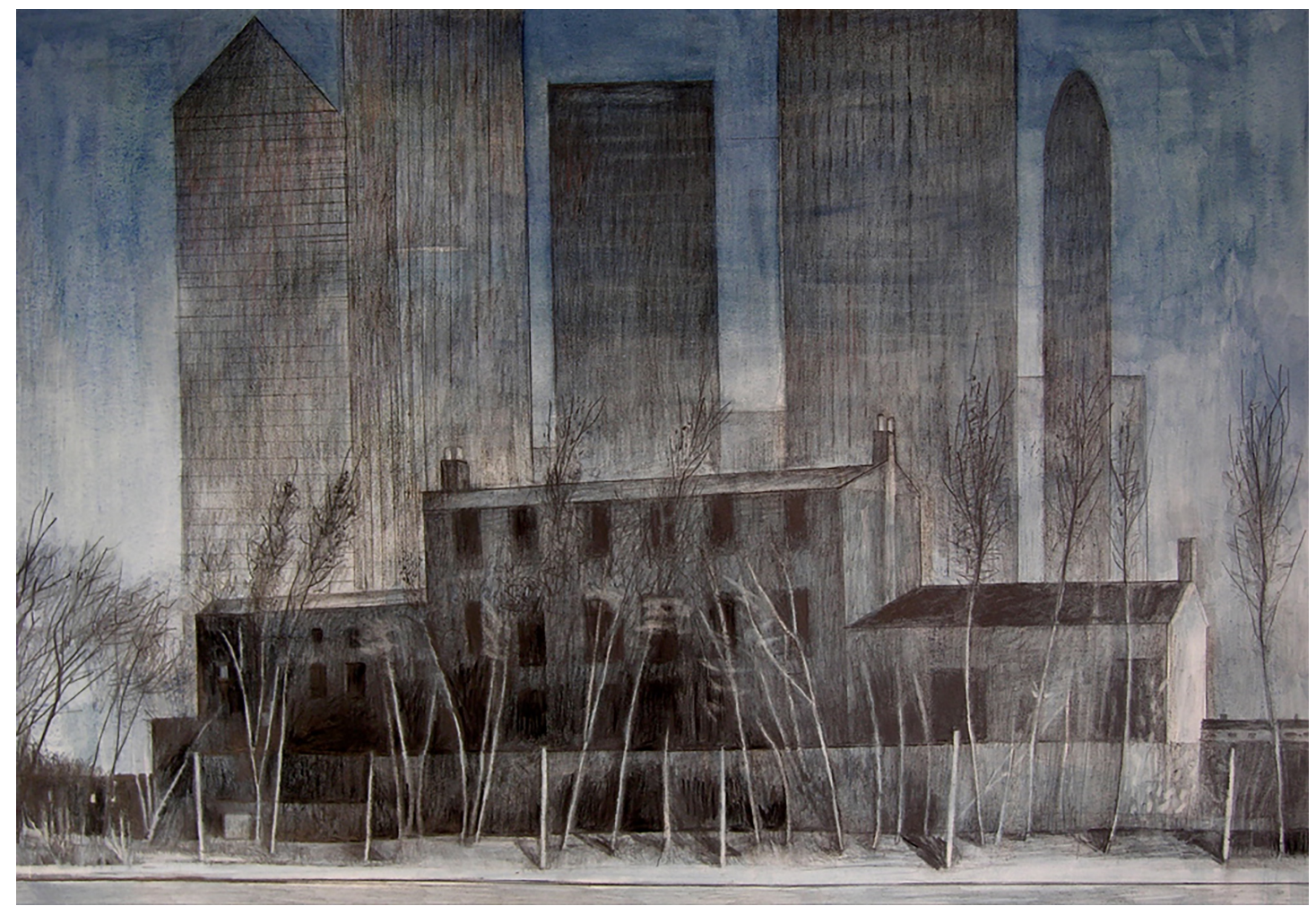

Figure 10 Howeson, Anne (2008) Coal and Fish Fictional Future

Paul Nash had a strong attachment to the English landscape. His work had a metaphorical quality - he looked for particular places and found idiosyncratic ways of representing them. $\mathrm{He}$ considered 'objects as personages,' calling his late1930s photos of animal-like fallen trees 'monsters'. When a mentor advised him to 'go for Nature' he said: 'I have tried ... to paint trees as though they were human beings,' (Nash, Paul August 1912 letter to Gordon Bottomley).

In a similar way, with the exhibition 'Remember Me,' although I intended to include figures in minor semi abstract roles, I came to see the buildings themselves as the personalities. Like the Eiffel Tower, described as the 'Shepherdess of Paris' by Apollinaire in his poem 'Zone' from 'Alcools' (1913), the warehouses, site offices, tenement blocks and towers of King's Cross were the lead characters - the lamp posts, cctv cameras and bollards the supporting cast.

I had just read WG Sebald's book 'Austerlitz' (2001), and was excited by his reference to memory and time. One passage in particular, set in Liverpool Street station during regeneration mentions 'a kind of heartache', caused by 'the vortex of past time' (Sebald 2001 p.182). He describes a station porter in a 'snow white turban' (not a white rabbit) who emerged from a 'low doorway in the builders' fence reaching up to the second story of the interior façade of the station' ... 'and now disappeared through it again with an odd jerk' (Sebald 2001 p.188). 
As though entering an underworld, Austerlitz follows the man through the doorway, into the disused Ladies Waiting Room on the other side, where the 'man in the turban was nowhere to be seen'. Later, the space seems to merge with other places from the past, reminiscent of a Piranesi print: 'vaults and brickwork arches bearing on them many - storied structures, with flights of stone steps, wooden stairways and ladders, all leading the eye on and on' (Sebald 2001: p.190).

\section{'Present in the past'}

The second project, 'Present in the Past' Collyer Bristow, 2015, developed from a meeting with Francis Marshall, curator at the Museum of London, who invited me to work with the Museum's prints and drawings archive. Taking copies of early engravings about King's Cross and St Pancras from London prints and drawings archives, I changed their scale, context and content (by erasing and re drawing) to evoke a sense of past and present in kind of palimpsest.

In both my King's Cross (KX) projects, I had no particular political agenda, but was motivated by a feeling of nostalgia for the disappearing and familiar places and a concern that the environment might become too corporate. But change is inevitable (the archive prints show successive disruptions and building works through previous centuries), and it has been exciting to watch the new public spaces emerging, with their eclectic mix of uses. The developers said they wanted to maintain existing communities and create new ones. At the start of the construction work they took the inspired decision of launching Central Saint Martins in Cubitt's Granary just north of the canal, creating an instant and vibrant new population, with crowds of artists streaming up the new King's Boulevard every morning towards Granary Square, where local children go bathing in the fountains in the summer - as if on a day out by the seaside. 


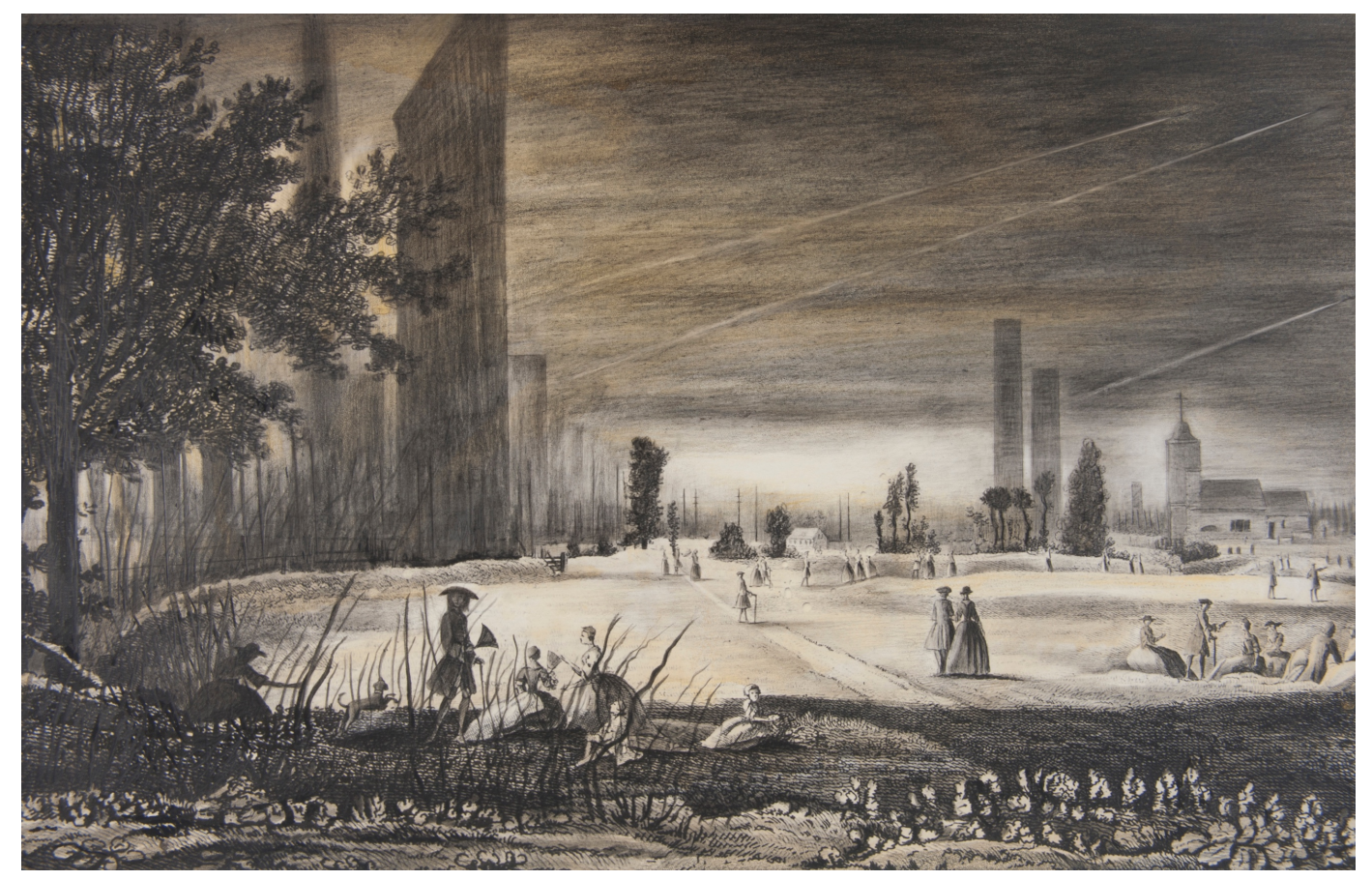

Figure 11 Howeson, Anne (2014) St Pancras in the Fields 1752

In the original prints, I discovered in archives for 'Present in the Past,' people were strolling with their dogs in parks and churchyards, men digging graves, workmen building railways. Soon my drawings began to include people too. Part document, part fiction, the drawings slowly developed, becoming a kind of 'conversation' with an earlier artist. As I drew on top of their drawings, almost walking in their footsteps, new stories blended with the old - the ghosts of past communities meeting people from the streets of today.

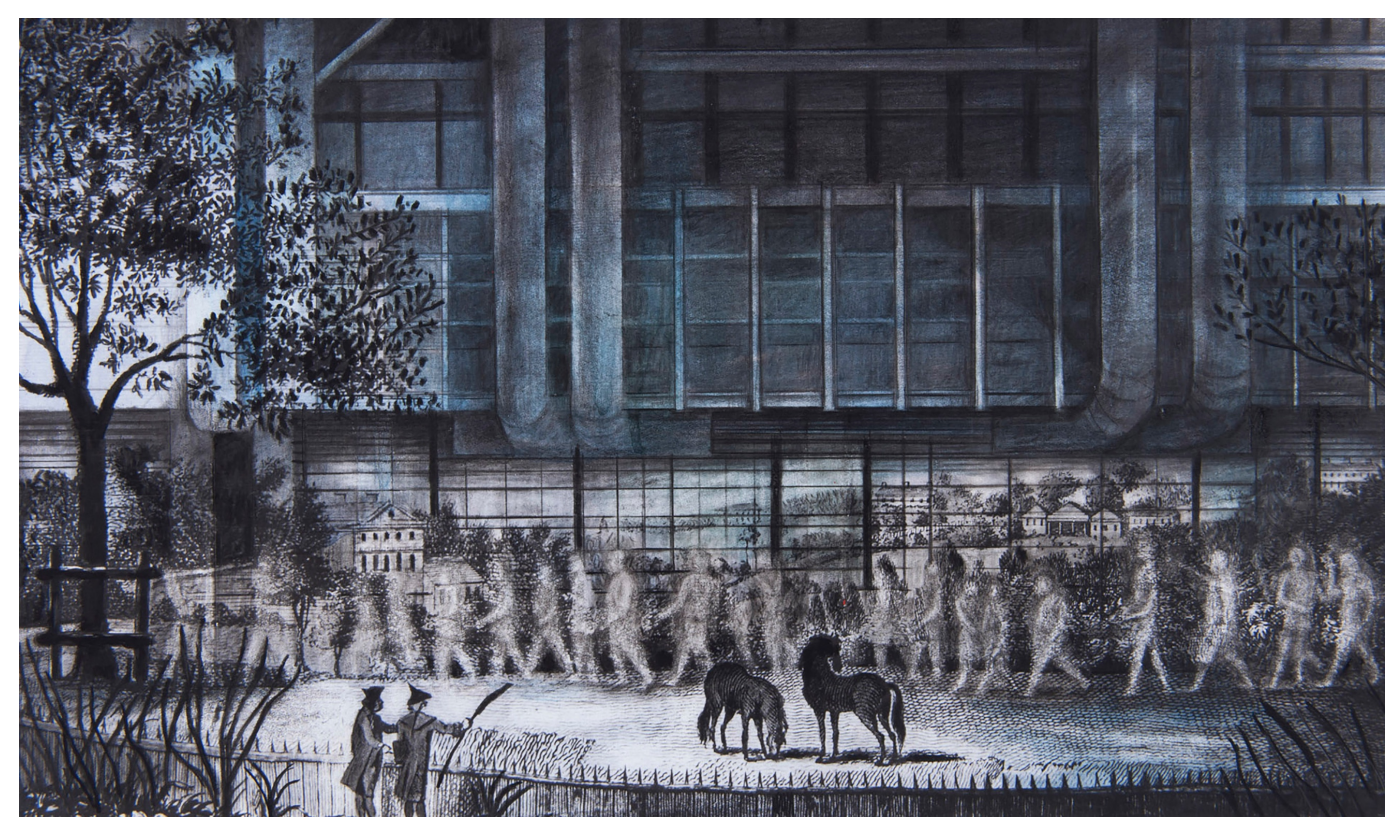

Figure 12 Howeson, Anne (2014) Hampstead Horses 
The King's Cross drawings are concerned with time, memory and place. They aim to make links between the experience of living now and living in the past - using place, landscape and the built environment as a metaphorical container for these ideas.

In academia and contemporary culture, imagination and memory are not often discussed, nor is poetry and beauty. The emphasis is on concept and theory, rather than a mix of instinct, feeling, reason and analysis. This creates a new kind of orthodoxy and replaces a more maverick and independent environment - where anything can happen.

As a tutor at the Royal College of Art, keen to promote drawing and productivity and believing that ordinary life offers extraordinary material for new projects, I wrote a simple drawing exercise for first year students, giving them an A6 sketchbook and asking them to make a quick 'memory' drawing daily: 'of an incident/observation from their daily life, a document/evocation/diary note, something seen and experienced, concerning places, objects or people'. (Excerpt from Brief). 'Memory' is used here to suggest the idea of recalling an experience, either focusing on the visual, the physical - or a mixture of the two.

Results vary. Sometimes the drawings are strongly attached to memory, at other times memory acts as a springboard to new ideas, to be developed later - mixing memory and imagination. Memory is only one of many doorways into an imaginative world (imagination can conjure ideas from other sparks, for example research, visual or verbal prompts, associations, or seemingly from nowhere) but it is a useful trigger. Quick line drawings are a good way to create radical ideas that can later develop into complex and ambitious projects.

Gaston Bachelard said memory is spatial rather than temporal - that while time is elusive, memories are motionless, as though fixed in space: 'In its countless alveoli space contains compressed time. That is what space is for.' (Bachelard 1958 Poetics of Space p8). 


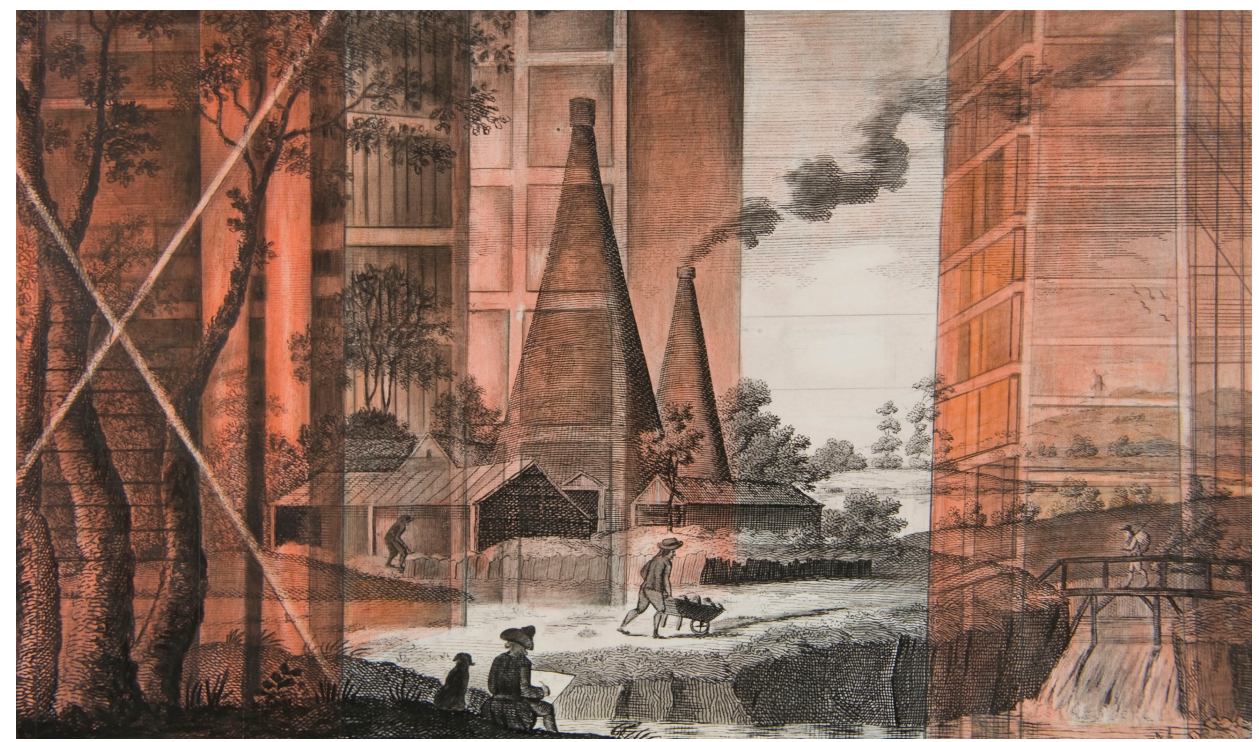

Figure 13 Howeson, Anne (2014) Tile Kilns

Place and space have a special relationship with memory and time in my work because architecture and landscape represent lived experience. People have always walked into rooms, across fields and forests and through the built environment. An awareness of past lives can be sensed everywhere in the layers under our feet, offering narratives, themes of loss, connection and renewal - rich material for new creative projects.

I felt, said Austerlitz, that the waiting room where I stood as if dazzled contained all the hours of my past life, all the suppressed and extinguished fears and wishes I had ever entertained, as if the black and white diamond pattern of the stone slabs beneath my feet were the board on which the end-game would be played, and it covered the entire plane of time. (Sebald 2001 Austerlitz p.192). 


\section{References}

Apollinaire, Guillaume (1913), Alcools, Paris: Editions Gallimard.

Bachelard, Gaston (1958), La Poétique de L'Espace, France: Universitaires de France.

Hertmans, Stefan (2001), Intercities, London: Reaktion.

Howeson, Anne (2015), 'Section D: From South Korea to King's Cross', Monocle Radio, UK, 10 February, https://monocle.com/radio/shows/section-d/174/. Accessed 23 March 2018.

Searle, Chris (1971), Fire Words, London: Jonathan Cape. Sebald, W. G. (2001), Austerlitz, Germany: C. Hanser.

\section{Suggested citation}

Howeson, A. (2018), 'Drawing and the remembered city', Journal of Illustration, 5:1, pp. 3-21, doi: 10.1386/jill.5.1.3_1

\section{Anne Howeson}

Anne Howeson is a Jerwood Drawing Prize winner, with work in the collection of the Museum of London and the Guardian News and Media. She lectures at the Royal College of Art, focusing on drawing and visual research. Ongoing drawing projects concern place, time and communities. Her first solo exhibition 'Remember Me' (The Guardian 2009) looked at regeneration at King's Cross. She was selected in 2014 for the Derwent Art prize and National Open Art Award. In 2011 and 2016 she was a Discerning Eye invited artist and was shortlisted for the Ruskin Prize in 2017. Her solo exhibitions, 'Present in the Past' (Collyer Bristow 2015) and 'Imagining King's Cross' (Cross Street Gallery 2015) appropriated digital fragments from source material in the Museum of London prints and drawings archive, reworking them in scale and content to evoke a sense of passing time.

Future plans include a multi discipline exhibition in the King's Cross regeneration area using sound, drawing and photography.

\section{Anne.Howeson@rca.ac.uk}

